\title{
Optimal delivery of follow-up care following pulmonary lobectomy for lung cancer
}

\author{
This article was published in the following Dove Press journal: \\ Lung Cancer:Targets and Therapy \\ 30 March 2016 \\ Number of times this article has been viewed
}

\section{Ying-Yi Chen \\ Tsai-Wang Huang \\ Hung Chang \\ Shih-Chun Lee}

Division of Thoracic Surgery, Department of Surgery, Tri-Service General Hospital, National Defense Medical Center, Taipei, Taiwan
Correspondence: Shih-Chun Lee Division of Thoracic Surgery, Department of Surgery, Tri-Service General Hospital, 325, Section 2, Cheng-Kung Road, Taipei I I 4, Taiwan, Republic of China Tel +88628792 7167

Fax +886287927403

Email leesc00I@yahoo.com.tw
Introduction: The rationale for oncologic surveillance following pulmonary lobectomy is to detect recurrent disease or a second primary lung cancer early enough so that an intervention can increase survival and/or improve quality of life. Therefore, we reviewed literature for international guidelines and reorganized these useful factors associated with non-small-cell lung cancer (NSCLC) recurrence as remedies in postoperative follow-up.

Method: The population of interest for this review was patients who had been treated with complete resection for primary NSCLC and were in follow-up.

Result: Guidelines on follow-up care for NSCLC vary internationally. Because of the production of progressive medical modalities, the current follow-up care should be corrected.

Conclusion: The specific follow-up schedule for computed tomography imaging may be more or less frequent, depending upon risk factors for recurrence. Many different predictors of postoperative recurrence may help to optimize the patient selection for specified surveillance guidelines and personalized adjuvant therapies to prevent possibly occult micrometastases and to get a better outcome.

Keywords: lung cancer, follow-up, surveillance, recurrence

\section{Introduction}

Lung cancer is the most commonly diagnosed cancer worldwide, with incidence rates continuing to increase in developing countries. ${ }^{1}$ Optimal follow-up care following pulmonary lobectomy for non-small-cell lung cancer (NSCLC) includes close surveillance for early detection of disease recurrence or second primary lung cancer and proper management for recurrence or second primary lung cancer. The majority of deaths in postresectional treatment of NSCLC are related to the development of recurrence. ${ }^{2,3}$ Close surveillance is required for survivors of lung cancer who have received definitive therapy but are at risk for recurrence of their disease and for the development of second primary lung cancers. ${ }^{4,5}$ There is a paucity of evidence for different follow-up strategies for patients with lung cancer as well as information about their cost effectiveness. International recommendations for follow-up after curative intent treatment for lung cancer are systematically reviewed comparing follow-up regimes in lung cancer. ${ }^{6}$ Multiple factors influence survival following disease recurrence. Risk factors of postoperative recurrence and/or metastatic disease in patients with NSCLC may enable us to optimize the patient selection for proper management with better outcome. However, few recent studies integrated the relationship of clinicopathologic variables and recurrence of NSCLC after pulmonary lobectomy in patients into the 
follow-up guiding principle. Therefore, we reviewed literature for international guidelines and reorganized these useful factors associated with NSCLC recurrence as remedies in postoperative follow-up.

\section{Methods}

\section{Search strategy}

We aimed at identifying all literature related to follow-up of patients with lung cancer. Searches were conducted in September and October 2015. Relevant articles were identified and retrieved from Ovid Medline and PubMed by internet search. The selected articles were staged according to the seventh edition of the American Joint Committee on Cancer adopted in 2009 . $^{7}$

\section{Inclusion and exclusion criteria}

The population of interest for this review was patients older than 18 years (with no upper age limit) who had been treated with complete resection for primary NSCLC and were in follow-up. All stages of lung cancer were included in the review. In line with previous reviews and published guidance, lung cancer follow-up is defined as care after treatment, which is planned and multifaceted. Primary outcomes included overall survival. Secondary outcomes were time to detection of recurrence or death. Only studies that reported at least one of the primary outcomes were included. Because of limited reported data, cost was not included as a formal outcome measure.

Recurrences in this review included locoregional recurrences and distant metastases. Although randomized controlled trials are widely regarded as the most appropriate design to evaluate efficacy of an intervention, a scoping review identified a paucity of studies using this design. This approach may potentially result in less robust studies being used for the development of evidence but provides the best evidence currently available in this underresearched area.

\section{Results}

Guidelines on follow-up care for NSCLC vary internationally and are listed in Table 1. There are five guidelines, including different follow-up frequency, clinical evaluation, and medical modality. Because of the production of progressive medical modalities, the current follow-up care should be corrected. Low-dose computed tomography (LDCT) ${ }^{8}$ or minimal-dose computed tomography $(\mathrm{MnDCT})^{9}$ without contrast may be a reasonable option over chest X-ray for detection of pulmonary lesions. The surveillance imaging frequency would be $3,6,12,18$, and 24 months and then annually after curative-intent therapy. Diagnostic chest CT with contrast plus upper abdomen scan is suggested to detect local recurrence or new primary lung cancer. If the patient is symptomatic, imaging modality specific to the patient's symptoms is recommended.

Table 2 lists the comparison of common clinicopathologic variables for recurrence of NSCLC following pulmonary lobectomy. These predictors included poor differentiation, squamous cell carcinoma (SCC), smoking history, tumor location, lymphovascular space invasion (LVSI), tumor maximum standard uptake value $\left(\mathrm{SUV}_{\max }\right)$, carcinoembryonic antigen (CEA) value, epidermal growth factor receptor (EGFR), and tumor size. The most common risk factor for recurrence of NSCLC following pulmonary lobectomy is poor differentiation.

Table I Comparison of international guidelines for follow-up after curative intent treatment for lung cancer

\begin{tabular}{|c|c|c|}
\hline Guidelines & Frequency & Clinical evaluation and medical modality \\
\hline $\mathrm{NCCN}^{16}$ & 6 months for 2 years, then annually & $\begin{array}{l}\text { History, clinical examination, and chest CT scan } \\
\text { with/without contrast for first } 2 \text { years, then noncontrast- } \\
\text { enhanced chest CT scan annually. }\end{array}$ \\
\hline $\begin{array}{l}\text { International consensus } \\
\text { statement }{ }^{17}\end{array}$ & $\begin{array}{l}3 \text { months for the first } 2 \text { years, then every } 6 \text { months } \\
\text { up to } 5 \text { years }\end{array}$ & $\begin{array}{l}\text { History, clinical examination, and chest X-ray-CT scans and } \\
\text { other tests should be performed in case of clinical indication } \\
\text { and smoking cessation. }\end{array}$ \\
\hline $\mathrm{NICE}^{18}$ & $\begin{array}{l}\text { All patients to be offered an initial specialist follow-up } \\
\text { appointment within } 6 \text { weeks of completing treatment } \\
\text { to discuss ongoing care. Offer regular appointments } \\
\text { thereafter, rather than relying on patients requesting } \\
\text { appointments when they experience symptoms }\end{array}$ & $\begin{array}{l}\text { Offer protocol-driven follow-up led by a lung cancer } \\
\text { clinical nurse specialist as an option for patients with a life } \\
\text { expectancy of more than } 3 \text { months. } \\
\text { Ensure that patients know how to contact the lung cancer } \\
\text { clinical nurse specialist involved in their care between their } \\
\text { scheduled hospital visits. }\end{array}$ \\
\hline $\mathrm{ACCP}^{8}$ & 6 months for 2 years, then annually & History, examination, imaging $\mathrm{CT}, \mathrm{CXR}$. \\
\hline $\mathrm{ESMO}^{19}$ & $\begin{array}{l}6 \text { months for first } 2 \text { years, and every } 12 \text { months } \\
\text { thereafter (for early-stage and locally advanced NSCLC) }\end{array}$ & History, physical examination, imaging. \\
\hline
\end{tabular}

Abbreviations: CXR, chest X-ray; NSCLC, non-small-cell lung cancer; CT, computed tomography; NCCN, National Comprehensive Cancer Network; NICE, National Institute for Health and Clinical Excellence; ACCP, American College of Chest Physicians; ESMO, European Society for Medical Oncology. 
Table 2 Comparison of common clinicopathologic variables for recurrence of NSCLC following pulmonary lobectomy

\begin{tabular}{|c|c|c|c|c|c|c|c|c|c|c|}
\hline \multirow[t]{2}{*}{ References } & \multicolumn{10}{|l|}{ Risk factors } \\
\hline & $\begin{array}{l}\text { Poor } \\
\text { differentiation }\end{array}$ & SCC & $\begin{array}{l}\text { Smoking } \\
\text { history }\end{array}$ & $\begin{array}{l}\text { Tumor } \\
\text { location }\end{array}$ & LVSI & $\begin{array}{l}\text { Tumor } \\
\text { SUV }_{\max }\end{array}$ & $\begin{array}{l}\text { CEA } \\
\text { value }\end{array}$ & EGFR & $\begin{array}{l}\text { Tumor } \\
\text { size }\end{array}$ & $\begin{array}{l}\text { Population } \\
\text { staging }\end{array}$ \\
\hline Zhang et $\mathrm{al}^{20}$ & + & - & - & + & + & - & - & - & + & IA \\
\hline Kuo et $\mathrm{al}^{21}$ & + & - & - & - & + & - & + & - & + & 1 \\
\hline Chen et $\mathrm{al}^{12}$ & + & - & - & - & + & - & - & - & - & I (pathologic stage) \\
\hline Chen et $\mathrm{al}^{3}$ & + & - & - & - & - & - & + & - & - & I (clinical stage) \\
\hline Park et $\mathrm{al}^{22}$ & - & - & - & - & - & + & - & - & - & $\mathrm{IA}$ \\
\hline Jiang et $\mathrm{al}^{23}$ & - & - & - & - & - & - & + & - & - & $\mathrm{IA}(<\mathrm{I} \mathrm{cm})$ \\
\hline Tao et $\mathrm{al}^{24}$ & - & + & - & - & + & - & - & - & - & IA \\
\hline $\mid z a r$ et $\mathrm{al}^{25}$ & - & - & - & - & - & - & - & + & + & IA \\
\hline Kobayashi et a ${ }^{26}$ & + & - & - & - & - & - & - & - & - & IA \\
\hline Kozu et a ${ }^{27}$ & - & - & - & - & - & - & + & - & + & 1 \\
\hline Choi et $\mathrm{al}^{28}$ & + & - & + & - & - & - & - & - & - & 1 \\
\hline Cho et $\mathrm{al}^{29}$ & + & - & - & - & - & - & - & - & - & I \\
\hline Guo et $\mathrm{al}^{30}$ & - & - & + & - & - & - & - & - & - & I-III \\
\hline Nguyen et $\mathrm{al}^{31}$ & - & - & - & - & - & + & - & - & - & I-III \\
\hline
\end{tabular}

Abbreviations: SCC, squamous cell carcinoma; LVSI, lymphovascular space invasion; SUV ${ }_{\text {max }}$ maximum standard uptake value; CEA, carcinoembryonic antigen; EGFR, epidermal growth factor receptor.

Table 3 lists the comparison of uncommon risk factors for postoperative recurrence of NSCLC. These factors were total lesion glycolysis (TLG), survivin overexpression, glucosylceramide synthase, fibroblast growth factor 9 , expression of Id-1 and VEGF, reactive oxygen species modulator 1 (Romo1) expression, FoxM1, preoperative peripheral lymphocyte count, Ki-67 labeling index, CD66b-positive neutrophil-to-CD8-positive lymphocyte ratio (iNTR), p53R2, preoperative plasma D-dimer, the significance and handling of microscopic invasion of NSCLC into hilar peribronchovascular soft tissue (SHEATH+), and tumor necrosis.

\section{Discussion}

The rationale for oncologic surveillance following initial treatment of lung cancer is to detect recurrent disease or a second primary lung cancer early enough so that an intervention

Table 3 Comparison of uncommon risk factors for postoperative recurrence of NSCLC

\begin{tabular}{|c|c|c|}
\hline References & Prognostic factor & Comment \\
\hline Park et al ${ }^{22}$ & TLG & A significant prognostic factor for OS in patients with Stage IA NSCLC \\
\hline Cho et $\mathrm{al}^{29}$ & Survivin overexpression & An independent predictor of recurrence and poor disease-free survival in resected NSCLC \\
\hline \multicolumn{3}{|l|}{ He et $a^{32}$} \\
\hline Zhang et $\mathrm{al}^{33}$ & Glucosylceramide synthase & $\begin{array}{l}\text { Contributes to the development of NSCLC and could be a useful prognostic indicator and } \\
\text { chemoresistance predictor for NSCLC patients }\end{array}$ \\
\hline Ohgino et $\mathrm{al}^{34}$ & Fibroblast growth factor 9 & A novel unfavorable prognostic indicator and a candidate therapeutic target of NSCLC \\
\hline Kim et $\mathrm{al}^{35}$ & Expression of Id-I and VEGF & A candidate for therapeutic target and a prognostic factor in NSCLC \\
\hline Lee et $\mathrm{al}^{36}$ & Romol expression & Significantly associated with early recurrence and poor survival in surgically resected NSCLC \\
\hline Xu et $\mathrm{a}^{37}$ & FoxMI & An independent risk factor for recurrence of NSCLC \\
\hline Zhang et $\mathrm{al}^{38}$ & $\begin{array}{l}\text { Preoperative peripheral } \\
\text { lymphocyte count }\end{array}$ & $\begin{array}{l}\text { An independent favorable prognostic factor of DFS in patients with NSCLC who underwent } \\
\text { lobectomy and lymph node dissection and adjuvant chemotherapy }\end{array}$ \\
\hline Yamashita et $\mathrm{al}^{39}$ & Ki-67 labeling index & $\begin{array}{l}\text { A prognostic factor of disease-free survival in NSCLC and the treatment of choice for patients } \\
\text { with positive LI may be considered, in addition to adjuvant chemotherapy, or lobectomy }\end{array}$ \\
\hline Ilie et $\mathrm{a}^{40}$ & iNTR & $\begin{array}{l}\text { Independent prognostic factor for a high rate of disease recurrence and poor OS in patients } \\
\text { with resectable NSCLC }\end{array}$ \\
\hline Hsu et $\mathrm{al}^{41}$ & p53R2 & A biomarker for overall survival and an indicator for tumor recurrence \\
\hline Wang et $\mathrm{a}^{42}$ & Preoperative plasma D-dimer & A poor prognostic factor within I year after the surgery in NSCLC \\
\hline Sakai et $\mathrm{al}^{43}$ & SHEATH + & Simply associated with central occurrence and advanced TNM stages \\
\hline Park et $\mathrm{al}^{44}$ & Tumor necrosis & $\begin{array}{l}\text { An adverse risk factor for survival and recurrence in patients with Stage IA NSCLC. Thus, } \\
\text { close observation and individualized adjuvant therapy might be helpful for patients with } \\
\text { Stage IA NSCLC with tumor necrosis. }\end{array}$ \\
\hline
\end{tabular}

Abbreviations: TLG, total lesion glycolysis; OS, overall survival; NSCLC, non-small-cell lung cancer; Romol, reactive oxygen species modulator I; DFS, disease-free survival; iNTR, CD66b-positive neutrophil-to-CD8-positive lymphocyte ratio; SHEATH+, the significance and handling of microscopic invasion of NSCLC into hilar peribronchovascular soft tissue; LI, labeling index; TNM, tumor-node-metastasis. 
can increase survival and/or improve quality of life. Even with completely resected early stage lung cancer, recurrence rates are high. Unfortunately, the majority of recurrences present at distant sites and have a poor prognosis, but a small proportion of patients do present with localized and potentially salvageable relapses. The majority of locoregional and distant recurrences occur within the first 2 years. ${ }^{10}$ When planning posttreatment surveillance, care should be taken to limit the number of CT scans if possible, particularly in younger individuals. There are no randomized trials comparing different surveillance strategies in patients with NSCLC. The evidence from observational studies and a systematic review of the literature $^{6}$ does not establish a clear-cut benefit for aggressive surveillance following treatment with curative intent. There are no data comparing full-dose, diagnostic, contrastenhanced CT with LDCT and MnDCT. Given the desire to minimize radiation exposure and the potential for continued screening for many years, some physicians use LDCT even in the initial period after NSCLC treatment. In view of new imaging modalities, such as $\mathrm{LDCT}^{8}$ and MnDCT scan, ${ }^{9}$ the radiation injury for patients with NSCLC after surgery could be enormously decreased. Patients who have had lung cancer are also at increased risk of a second primary, particularly of the lung, and may benefit from early detection of a second primary as well as from detection of a local recurrence. Therefore, annual $\mathrm{LDCT}^{8}$ may be continued beyond 3 years for patients who have no evidence of disease since these individuals are at risk for a second primary lung cancer as well as for recurrence. The specific follow-up schedule for CT imaging may be more or less frequent, depending upon risk factors for recurrence.

In a series of 1,073 patients who underwent a complete resection, recurrent NSCLC was identified in 445 patients $(41 \%) .{ }^{11}$ The median time to recurrence following surgery was 11.5 months, and the median survival following recurrence was 8.1 months. Multivariate analysis identified several factors that predicted shorter survival following recurrence. These included poor performance status, disease-free interval of 1 year or less, prior use of neoadjuvant chemotherapy or adjuvant radiotherapy, and distant metastases (as opposed to intrathoracic recurrence alone). In our previous research, ${ }^{3}$ 261 patients with clinical Stage I NSCLC after complete resection and dissection of mediastinal lymph nodes were reviewed. Only 17 patients $(6.5 \%)$ had locoregional recurrences, and $20(7.66 \%)$ of the same population had distant metastases. We found that tumor differentiation and serum CEA were independent predicators of postoperative relapse for clinical Stage I NSCLC after surgical resection. Risk factors of postoperative recurrence in patients with NSCLC may enable us to optimize the patient selection for postoperative adjuvant therapies to prevent possibly occult micrometastases. ${ }^{12}$ One of the purposes of this study is to get together all possible predictors of postoperative recurrences in patients with NSCLC (Tables 2 and 3). However, what kind of surveillance duration and follow-up modalities could really benefit these selected patients with specific risk factors of postoperative recurrence of NSCLC? Prospective multi-institutional studies or randomized clinical trials are mandatory to further validate the predictors of recurrence in NSCLC and specially designated surveillance guidelines for these selected patients.

Currently there is no established indication for targeted agents as adjuvant therapies outside of a clinical trial setting for patients with resectable NSCLC, and its use in this setting is controversial. There is suggestive evidence that EGFR mutationpositive early stage patients have a superior recurrence-free survival with erlotinib, particularly patients with resected Stage IIIA N2 disease. ${ }^{13,14}$ Whether this translates to an improvement in overall survival or merely delays recurrence is unknown. Randomized clinical trials are evaluating the role of EGFR- or ALK-targeted therapies in the adjuvant setting for molecularly selected patients. The rapid progression of molecular biology and genetic technique provide clinicians with tools to diagnose and treat diseases more precisely. EGFR mutation test can sieve out suitable cases, who are sensitive to EGFR TKIs, from patients with recurrences of NSCLC after adjuvant erlotinib therapy. ${ }^{13,14}$ Besides, immune checkpoint inhibitors, which unleash a patient's own T-cells to kill tumors, are revolutionizing cancer treatment. Rizvi et al ${ }^{15}$ used whole-exome sequencing of NSCLC samples treated with pembrolizumab, an antibody targeting programmed cell death-1 (PD-1) to unravel the genomic determinants of response to this therapy. The results suggest that the genomic landscape of lung cancers shapes response to anti-PD-1 therapy.

\section{Conclusion}

Annual LDCT, which causes less radiation harm, may be continued beyond 3 years for patients who have no evidence of disease since these individuals are at risk for a second primary lung cancer as well as for recurrence. The specific follow-up schedule for CT imaging may be more or less frequent, depending upon risk factors for recurrence. Many different predictors of postoperative recurrence in patients with NSCLC may enable us to optimize the patient selection for specified surveillance guidelines and design personalized 
adjuvant therapies to prevent possibly occult micrometastases and to get better outcome.

\section{Disclosure}

There was no substantial direct or indirect commercial financial incentive associated with publishing this article. The authors report no conflicts of interest in this work.

\section{References}

1. Alberg AJ, Ford JG, Samet JM, et al. Epidemiology of lung cancer: ACCP evidence-based clinical practice guidelines (2nd edition). Chest. 2007;132:29S-55S.

2. Taylor MD, Nagji AS, Bhamidipati CM, et al. Tumor recurrence after complete resection for non-small cell lung cancer. Ann Thorac Surg. 2012;93:1813-1820; discussion 1820-1821.

3. Chen YY, Huang TW, Tsai WC, et al. Risk factors of postoperative recurrences in patients with clinical stage I NSCLC. World $J$ Surg Oncol. 2014;12:10.

4. Clark MM, Novotny PJ, Patten CA, et al. Motivational readiness for physical activity and quality of life in long-term lung cancer survivors Lung Cancer. 2008;61:117-122.

5. Yang P. Epidemiology of lung cancer prognosis: quantity and quality of life. Methods Mol Biol. 2009;471:469-486.

6. Calman L, Beaver K, Hind D, et al. Survival benefits from follow-up of patients with lung cancer: a systematic review and meta-analysis. J Thorac Oncol. 2011;6:1993-2004.

7. American Joint Committee on Cancer. AJCC Cancer Staging Manual. 7th ed. New York: Springer; 2010.

8. Colt HG, Murgu SD, Korst RJ, et al. Follow-up and surveillance of the patient with lung cancer after curative-intent therapy: diagnosis and management of lung cancer, 3rd ed: American College of Chest Physicians evidence-based clinical practice guidelines. Chest. 2013;143:e437S-e454S.

9. Brouwers MC, Kho ME, Browman GP, et al. AGREE II: advancing guideline development, reporting and evaluation in health care. CMAJ. 2010;182:E839-E842.

10. Lou F, Sima CS, Rusch VW, et al. Differences in patterns of recurrence in early-stage versus locally advanced non-small cell lung cancer. Ann Thorac Surg. 2014;98:1755-1760; discussion 1760-1761.

11. Sugimura H, Nichols FC, Yang P, et al. Survival after recurrent nonsmallcell lung cancer after complete pulmonary resection. Ann Thorac Surg. 2007;83:409-417; discussion 417-418.

12. Chen YY, Huang TW, Tsai WC, et al. Lymphovascular space invasion and tumor differentiation are predictors for postoperative recurrence in patients with pathological stage I nonsmall cell lung cancer. $J$ Chin Med Assoc. 2014;77:416-421.

13. Pennell NA, Neal JW, Chaft JE, et al. SELECT: a multicenter phase II trial of adjuvant erlotinib in resected early-stage EGFR mutationpositive NSCLC. J Clin Oncol. 2014;32:5s.

14. Shepherd FA, Altorki NK, Eberhardt WE, et al. Adjuvant erlotinib (E) versus placebo $(\mathrm{P})$ in non-small cell lung cancer (NSCLC) patients (pts) with tumors carrying EGFR-sensitizing mutations from the RADIANT trial. J Clin Oncol. 2014;32:5s.

15. Rizvi NA, Hellmann MD, Snyder A, et al. Cancer immunology. Mutational landscape determines sensitivity to PD-1 blockade in non-small cell lung cancer. Science. 2015;348:124-128.

16. David SEDE, Wallace A, et al. NCCN Clinical Practice Guidelines in Oncology: Non-Small Cell Lung Cancer. Version 7. Fort Washington, PA: National Comprehensive Cancer Network; 2015.

17. Saunders M, Sculier JP, Ball D, et al. Consensus: the follow-up of the treated patient. Lung Cancer. 2003;42 (Suppl 1):S17-S19.

18. National Institute for Health and Clinical Excellence. The Diagnosis and Treatment of Lung Cancer. London, UK: National Institute for Health and Clinical Excellence; 2011.
19. Crino L, Weder W, van Meerbeeck J, et al. Early stage and locally advanced (non-metastatic) non-small-cell lung cancer: ESMO Clinical Practice Guidelines for diagnosis, treatment and follow-up. Ann Oncol. 2010;21(Suppl 5):v103-v115.

20. Zhang Y, Sun Y, Xiang J, et al. A clinicopathologic prediction model for postoperative recurrence in stage Ia non-small cell lung cancer. J Thorac Cardiovasc Surg. 2014;148:1193-1199.

21. Kuo SW, Chen JS, Huang PM, et al. Prognostic significance of histologic differentiation, carcinoembryonic antigen value, and lymphovascular invasion in stage I non-small cell lung cancer. $J$ Thorac Cardiovasc Surg. 2014;148:1200-1207, e1203.

22. Park SY, Cho A, Yu WS, et al. Prognostic value of total lesion glycolysis by $18 \mathrm{~F}-\mathrm{FDG}$ PET/CT in surgically resected stage IA non-small cell lung cancer. J Nucl Med. 2015;56:45-49.

23. Jiang W, Pang X, Xi J, et al. Clinical outcome of subcentimeter non-small cell lung cancer after surgical resection: single institution experience of 105 patients. J Surg Oncol. 2014;110:233-238.

24. Tao H, Hayashi T, Sano F, et al. Prognostic impact of lymphovascular invasion compared with that of visceral pleural invasion in patients with pN0 non-small-cell lung cancer and a tumor diameter of $2 \mathrm{~cm}$ or smaller. J Surg Res. 2013;185:250-254.

25. Izar $B$, Sequist $L$, Lee $M$, et al. The impact of EGFR mutation status on outcomes in patients with resected stage I non-small cell lung cancers. Ann Thorac Surg. 2013;96:962-968.

26. Kobayashi N, Toyooka S, Soh J, et al. Risk factors for recurrence and unfavorable prognosis in patients with stage I non-small cell lung cancer and a tumor diameter of $20 \mathrm{~mm}$ or less. J Thorac Oncol. 2007;2:808-812.

27. Kozu Y, Maniwa T, Takahashi S, et al. Risk factors for both recurrence and survival in patients with pathological stage I non-small-cell lung cancer. Eur J Cardiothorac Surg. 2013;44:e53-e58.

28. Choi PJ, Jeong SS, Yoon SS. Prognosis of recurrence after complete resection in early-stage non-small cell lung cancer. Korean J Thorac Cardiovasc Surg. 2013;46:449-456.

29. Cho S, Park TI, Lee EB, et al. Poor prognostic factors in surgically resected stage I non-small cell lung cancer: histopathologic and immunohistochemical analysis. Korean J Thorac Cardiovasc Surg. 2012:45:101-109.

30. Guo NL, Tosun K, Horn K. Impact and interactions between smoking and traditional prognostic factors in lung cancer progression. Lung Cancer. 2009;66:386-392.

31. Nguyen XC, Lee WW, Chung JH, et al. FDG uptake, glucose transporter type 1, and Ki-67 expressions in non-small-cell lung cancer: correlations and prognostic values. Eur J Radiol. 2007;62:214-219.

32. He L, Hou M, Zhang J, et al. [Subcellular localization of survivin in non-small cell lung cancer.] Ai Zheng 2009;28:955-960. Chinese.

33. Zhang C, Lin X, Song Y, et al. Overexpression of glucosylceramide synthase and its significance in the clinical outcome of non-small cell lung cancer. Chin Med J (Engl). 2014;127:3071-3076.

34. Ohgino K, Soejima K, Yasuda H, et al. Expression of fibroblast growth factor 9 is associated with poor prognosis in patients with resected nonsmall cell lung cancer. Lung Cancer. 2014;83:90-96.

35. Kim MS, Park TI, Lee YM, et al. Expression of Id-1 and VEGF in nonsmall cell lung cancer. Int J Clin Exp Pathol. 2013;6:2102-2111.

36. Lee SH, Min JW, Lee JS, et al. Reactive oxygen species modulator 1 (Romo1) overexpression is an independent predictor of poor survival in NSCLC patients who undergo surgical resection. Lung Cancer. 2015;87:45-52.

37. Xu N, Wu SD, Wang H, et al. Involvement of FoxM1 in non-small cell lung cancer recurrence. Asian Pac J Cancer Prev. 2012;13:4739-4743.

38. Zhang J, Huang SH, Li H, et al. Preoperative lymphocyte count is a favorable prognostic factor of disease-free survival in non-small-cell lung cancer. Med Oncol. 2013;30:352.

39. Yamashita S, Moroga T, Tokuishi K, et al. Ki-67 labeling index is associated with recurrence after segmentectomy under video-assisted thoracoscopic surgery in stage I non-small cell lung cancer. Ann Thorac Cardiovasc Surg. 2011;17:341-346. 
40. Ilie M, Hofman V, Ortholan C, et al. Predictive clinical outcome of the intratumoral CD66b-positive neutrophil-to-CD8-positive T-cell ratio in patients with resectable nonsmall cell lung cancer. Cancer. 2012;118:1726-1737.

41. Hsu NY, Wu JY, Liu X, et al. Expression status of ribonucleotide reductase small subunits hRRM2/p53R2 as prognostic biomarkers in stage I and II non-small cell lung cancer. Anticancer Res. 2011;31:3475-3481.

42. Wang Z, Fu J, Diao D, et al. [Pre-operative plasma D-dimer level may predict the poor prognosis within one year after the surgery for nonsmall cell lung cancer.] Zhongguo Fei Ai Za Zhi. 2011;14:534-537. Chinese.
43. Sakai Y, Ohbayashi C, Kanomata N, et al. Significance of microscopic invasion into hilar peribronchovascular soft tissue in resection specimens of primary non-small cell lung cancer. Lung Cancer. 2011;73:89-95.

44. Park SY, Lee HS, Jang HJ, et al. Tumor necrosis as a prognostic factor for stage IA non-small cell lung cancer. Ann Thorac Surg. 2011;91:1668-1673.

\section{Publish your work in this journal}

Lung Cancer: Targets and Therapy is an international, peer-reviewed, open access journal focusing on lung cancer research, identification of therapeutic targets and the optimal use of preventative and integrated treatment interventions to achieve improved outcomes, enhanced survival and quality of life for the cancer patient. Specific topics covered in the journal include: Epidemiology, detection and screening; Cellular research and biomarkers; Identification of biotargets and agents with novel mechanisms of action; Optimal clinical use of existing anticancer agents, including combination therapies; Radiation and surgery; Palliative care; Patient adherence, quality of life, satisfaction; Health economic evaluations. The manuscript management system is completely online and includes a very quick and fair peer-review system. Visit http://www.dovepress.com/testimonials.php to read real quotes from published authors. 